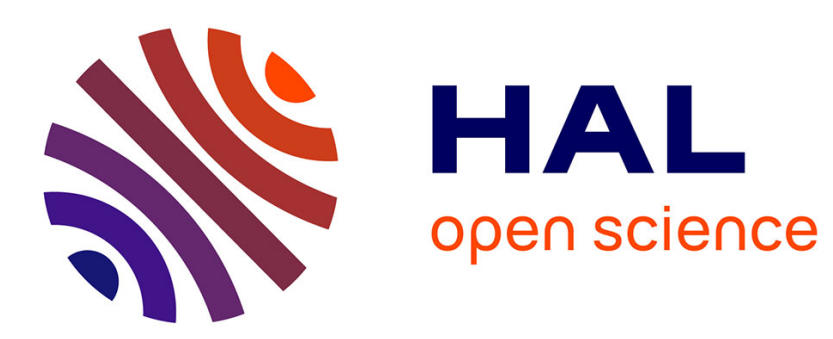

\title{
Analyzing the use of history in mathematics education: issues and challenges around Balacheff's cK model
}

Thomas de Vittori

\section{To cite this version:}

Thomas de Vittori. Analyzing the use of history in mathematics education: issues and challenges around Balacheff's cK model. Educational Studies in Mathematics, 2018, 99 (2), pp.125 - 136. 10.1007/s10649-018-9831-6 . hal-01915902

\section{HAL Id: hal-01915902 \\ https://hal.science/hal-01915902}

Submitted on 8 Nov 2018

HAL is a multi-disciplinary open access archive for the deposit and dissemination of scientific research documents, whether they are published or not. The documents may come from teaching and research institutions in France or abroad, or from public or private research centers.
L'archive ouverte pluridisciplinaire HAL, est destinée au dépôt et à la diffusion de documents scientifiques de niveau recherche, publiés ou non, émanant des établissements d'enseignement et de recherche français ou étrangers, des laboratoires publics ou privés. 
Running head: HISTORY IN MATHEMATICS EDUCATION: BALACHEFF'S CKØ MODEL 1

Analyzing the use of history in mathematics education: issues and challenges around Balacheff's

$$
\mathrm{cK} \not \text { model }
$$

Thomas de Vittori

Université d'Artois - Laboratoire de Mathématiques de Lens - France

\section{Contact:}

\section{DE VITTORI Thomas}

23 rue Victor Hugo

59950 AUBY

FRANCE

thomas.devittori@espe-lnf.fr 


\title{
HISTORY IN MATHEMATICS EDUCATION: BALACHEFF’S CKØ MODEL
}

\begin{abstract}
Part of the international reflection on the use of history in mathematics teaching consists in a quest of frameworks and models suitable for empirical studies. Following this demand, this paper explores the way Balacheff's cK $\varnothing$ model, a model taken from the didactics of mathematics, can be used in the analysis of learning at student level. In the first part of this paper, Balacheff's cK $\varnothing$ model (conceptions, Knowledge, $\varnothing$ oncepts) is shortly presented, and in the second part, the relationship between the epistemological background of the model and the use of the history of mathematics is explored in order to show a possible suitableness. The third part addresses an example of a school activity (about ancient Indian geometry) in which the model is applied and the historical issues clarified. Questioning the role of problems both in the cKф model and in the use of history, the last part shows how a study at the students' conceptions level enlightens the way in which historical elements can interact with contemporary mathematical learning.
\end{abstract}

Keywords: history of mathematics, didactics, epistemology, $\mathrm{cK} \phi$ model 


\section{HISTORY IN MATHEMATICS EDUCATION: BALACHEFF'S CKØ MODEL}

Analyzing the use of history in mathematics education: issues and challenges around Balacheff's $\mathrm{cK} \phi$ model

For approximately thirty years now, the relevance of the history of mathematics in mathematics education has always been reaffirmed by many educators and researchers almost all over the world. However, at the same time, what makes such a pedagogical approach interesting is still an unclear point especially when one is looking at the students' learning. Facing this paradoxical situation, since the beginning of the 21st century, the international community of people involved in such a practice has been asking for more empirical studies that could enlighten the role of historical elements in mathematics teaching. Fried, Guillemette \& Jahnke (2016) have very recently tried to summarize this quest of theoretical frameworks suitable for the analysis of history in mathematics education and they have noted that studies on the pedagogical use of history should not miss the specificities of the historical knowledge. Fried et al. reject the idea of a theoretical framework only driven by history as a tool, and according to them, "theoretical frameworks for history of mathematics in mathematics education, as theoretical frameworks, should be driven by questions centered on the historical character of mathematics, on the historical conditioning of our experience of mathematics, and, generally, the meaning of our relationship to the past." (Fried et al., 2016). Some promising results can be found in the works of Jankvist (2009), Guillemette (2015), Jahnke (2014), Fried (2008, 2014a, 2014b) and Wang, Wang, Li \& Rugh (2018). A good example of a pedagogical use of history that tries to take into account these warnings is certainly the hermeneutic approach by Jahnke, whose main points have been very recently recalled by the author himself (Fried et al., 2016). According to Jahnke, the hermeneutic approach is "one of the more sophisticated approaches to history of mathematics in the classroom". This pedagogical "procedure can be summarized in 6 principles. 


\section{HISTORY IN MATHEMATICS EDUCATION: BALACHEFF’S CKØ MODEL}

(1) Students study a historical source after they have acquired a good understanding of the respective mathematical topic in a modern form and a modern perspective. [...] (2) Students gather and study information about context and biography of the author. (3) The historical peculiarity of the source is kept as far as possible. (4) Students are encouraged to produce free associations. (5) The teacher insists on reasoned arguments, but not on accepting an interpretation which has to be shared by everybody. (6) The historical understanding of a concept is contrasted with the modern view, that is the source should encourage processes of reflection" (Fried et al., 2016). Thus, the hermeneutic approach can be conceived as a process whose achievement is the sixth and last point: a confrontation between a modern understanding and a historical understanding of mathematical objects. This framework as proposed by Jahnke raises one of the subtle questions about the interactions between the past and student contemporary learning. In the following paragraphs, I will study a model taken from the didactics of mathematics can be helpful in the identification and analysis of such a key moment in students' tasks when classroom activities blend history and mathematics. The Balacheff's $\mathrm{cK} \phi$ model presented in this paper is an attempt to address this question at the student level, especially in the case of empirical studies.

\section{The cKe model}

Nicolas Balacheff is a French researcher whose work mainly addresses computer-based learning. In 1985, his early interest in mathematics education led him to elaborate a theoretical model that could help the analysis of mathematics learning when exercises were implemented via a computer. The theoretical framework in which he is working is Brousseau's Theory of Didactical Situations (TDS): “[...] with the project of bridging artificial intelligence and didactics of mathematics, and the objective of enhancing the design of computer-based learning 


\section{HISTORY IN MATHEMATICS EDUCATION: BALACHEFF’S CKØ MODEL}

environments. The design of these environments had a ternary structure including a model of the learner, a model of the content to be learned and an instructional model.” (Balacheff, 2013, p.2) The main point for the study of history in mathematics education is that Balacheff's model is deeply anchored at an epistemological level and does not focus on the psychological part of any learning. As we will see later, this specificity is one of the main aspects that makes this framework a valuable first step in an empirical analysis of the use of the history of mathematics. Of course, many other ways are possible, especially methods associated with psychological topics (Lim \& Chapman, 2015, on motivation for instance), but these aspects are not what I intend to address in this paper. Let us come back to the model that will be used. The main idea in Balacheff's research is a new work on conceptions that he defines as a "state of dynamical equilibrium of an action/feedback loop between a learner and a milieu under proscriptive constraints of viability." (Balacheff, 2013, p.5) Actions and feedbacks are key elements in Brousseau's theory, which is Balacheff's main theoretical framework. Actions are what the learner does (or can do), and feedback stresses the way in which everything that the learner is in contact with (the material content as well as the relationships with other students) produces a retroaction. In this context, conception has to be understood as a local knowledge of a learner in a specific situation. Balacheff defines it as a "dynamical equilibrium" because it is built on action/feedback loops that could at each time destabilize the learner's knowledge. For instance, doing multiplications with integers tends to give this operation some properties (multiplying two numbers gives a result greater than each one of them) that can be challenged by using decimal numbers ( 0.2 times 5 gives 1 , which is not greater than 5$)$. All of this is, in a certain way, in the TDS. What is new in Balacheff's concept appears when he tries to make the "conception" an operational notion (for computer-based learning for instance). His characterization is as follows: 


\section{HISTORY IN MATHEMATICS EDUCATION: BALACHEFF'S CKC MODEL}

"I call conception a quadruplet $(\mathrm{P}, \mathrm{R}, \mathrm{L}, \Sigma)$ in which:

- $\mathrm{P}$ is a set of problems.

- $\mathrm{R}$ is a set of operators.

- $\mathrm{L}$ is a representation system.

$-\Sigma$ is a control structure.

The first three elements are almost directly borrowed from the Vergnaud triplet. The vocabulary is different to avoid confusion with the vocabulary of psychology.

$[\ldots]$

The forth element of the quadruplet, the control structure, includes behaviors such as making choices, assessing feedback, making decisions, judging the advancement of a problem solving process. These metacognitive behaviors are more often than not silent and invisible, hence rarely accessible to observation. It is why, to overcome this difficulty, one uses specific experimental settings, for example inviting learners to work in pairs, with the expectation that this will be enough to elicit these behaviors." (Balacheff, 2013, p.6)

The second part of this paper will explain how this quadruplet perfectly fits some situations in which historical elements have been introduced, but I can now provide a few more explanations on the four categories: $\mathrm{P}, \mathrm{R}, \mathrm{L}$ and $\Sigma$. P, the set of problems, is directly inspired by the epistemological background of the TDS. According to Brousseau and to Balacheff as well, mathematics knowledge is elaborated as an answer to problems. Part of the work of the mathematician is the identification of problems that can be solved in the same manner, that is, with the same conceptual tools. Thus, a "set of problems" can be spotted, and this family gives a conception its meaning and its usefulness. Balacheff gives the example of conceptions about the tangent that appears in a large set of situations. $\mathrm{R}$, the set of operators, tends to express all the techniques that enable the transformation of the problem. Indeed, in problem solving, one has to modify the initial situation step by step in order to make it finally suitable to a well-known 


\section{HISTORY IN MATHEMATICS EDUCATION: BALACHEFF’S CKØ MODEL}

theorem or to a calculus procedure. In the analysis of a conception, the set of operators contains all the mathematical procedures available to the learner. The L letter may be the most obvious. It refers to the way in which a problem is presented. In fact, the representation system is related to the mathematical language used in the situation. Modern algebra is one example, but as we will see later, older systems of representation, such as knots on pieces of string in the Inca's quipus, are also possible. The last point is $\Sigma$, the control structure. As explained by Balacheff himself in the above quote, it is something he introduces in order to make what is at stake visible when the learner identifies how close to the solution he is. In other words, each time someone is solving a mathematical problem, consciously or not, he is using some elements that help him in the control of what is done. For instance, when pupils multiply 456 by 123 , they use an algorithm in which each step gives a way to control the advancement of the calculus. For Balacheff, this fourth item in his definition of conception is unavoidable in computer-based learning, as it enables an analysis before the action of what can be done by the student.

The model presented in this first part of this paper is called $\mathrm{cK} \phi$ by its designer. "The name $\mathrm{cK} \phi$ comes from the names of the three pillars of the model: conception, knowing, concept. I keep the word "knowledge" to name a conception which is identified and formalized by an institution (which is a body of an educational system in our case)." (Balacheff, 2013) To give the model a good coherence, each of the three words is carefully defined. The first c (the conceptions) has been recalled in the above paragraph, so let us look at $\mathrm{K}$ and $\varnothing$.

"I call "concept" the set of all conceptions having the same object with respect to $C \mu$ ".

This definition is aligned with the idea that a mathematical concept is not reduced to the text of its

1 "To have the same object with respect to a conception $\mathrm{Ca}$ " sets an equivalence relation among conceptions. Let us now claim the existence of a conception $\mathrm{C} \mu$ more general than any other conception to which it can be compared; this seems to be an abstract declaration, but pragmatically, it corresponds to a piece of a mathematical theory. (Balacheff, 2013) 


\section{HISTORY IN MATHEMATICS EDUCATION: BALACHEFF'S CKØ MODEL}

formal definition, but is the product of its history and of the set of practices in different communities.

$[\ldots]$

I call "knowing" any subset of a concept which can be ascribed to a cognitive subject or a

community.

In practical terms, this definition of conception and knowing provides a framework which preserves learners' epistemic integrity despite contradictions and variability across situations.

$[\ldots]$

a conception is the instantiation of a knowing by a situation (it characterizes the subject/milieu system in a situation), or a conception is the instantiation of a concept by a pair (subject/situation)."

(Balacheff, 2013, p.11)

In a nutshell, one can say that Balacheff creates some equivalent classes in order to show links between the most abstract mathematics (the concepts), what is taught (the knowledge) and what is effectively used/understood by pupils (the conceptions). It is important to state that this process is mainly a bottom-up process because the main entry is the conception at the student level.

\section{2. cKe model and history of mathematics}

As explained by the historian of biology Morange (Morange, 2008), the history of science, which was conceived in the French tradition of the twentieth century from Alexandre Koyré to Georges Canguilhem, is both epistemological and philosophical ${ }^{2}$. Of course, this is not the only way to refer to the history of science, and in fact, the major part of current research in this field is more inspired by sociology than by philosophy. A few experiments on the use of the history of science in education address this social approach, which can be very interesting when the purpose is related to the cultural part of mathematics (Grugnetti et al., 2002).

2 "Le rôle que nous donnons à l'histoire des sciences est également épistémologique et philosophique. L'histoire telle que nous la concevons est une histoire des idées, des concepts et des modèles, donc à la fois une histoire et une philosophie des sciences telles qu'elles ont été conçues dans la tradition française du XXe siècle, d'Alexandre Koyré à Georges Canguilhem." (Morange, 2008, pp.18-19) 


\section{HISTORY IN MATHEMATICS EDUCATION: BALACHEFF’S CKØ MODEL}

Balacheff mainly follows the French tradition, and his $\mathrm{cK} \phi$ model works at an epistemic level in which each concept is produced by "its history and [...] set of practices" (Balacheff, 2013, p.11). Mathematical concepts are viewed not only as pure abstractions coming from nowhere but also as processes in which historical elements can be regarded as witnesses of their evolution. Thus, by itself, the $\mathrm{cK} \phi$ model seems to be able to present an opportunity to question the historical part in mathematics education, but how?

Balacheff's model is set on three different levels. In each one, the history of mathematics does not appear in the same way. The mathematical concepts are obviously the goal of mathematics education, and we have just seen that the $\varnothing$ level gives the last product of both history and teaching. Concepts, such as functions, numbers and numeral systems, and geometrical shapes, are considered as autonomous (for the coherence of the model) and historically founded, even if they often appear in an ahistorical way (that is, without any explicit historical anchorage). On the $\mathrm{K}$ stage, mathematical contents are ascribed to a real person or to a human community. On this level, one can consider how different groups of people think about such or such a concept, and some borders can therefore be drawn, especially between the ancient way and the contemporary way of doing mathematics. A historian's work is, by the way, the main motor of this process, as it gives information on the past. An important point is that this $\mathrm{K}$ level leads to a structural gap between knowledge. As they are ascribed to a specific group, some $\mathrm{K}$ can be unreachable to another group. This is particularly true in the case of historical versus contemporary ones because the only way to think exactly as ancients think would be to become one of the ancients, which is impossible. Of course, someone can do as if, but it will always be as if, the meaning of which I will try to explain below. Through the $\mathrm{cK} \phi$ model, which aims at didactical studies, there is a systemic gap between, for instance, the way we contemporarily think 


\section{HISTORY IN MATHEMATICS EDUCATION: BALACHEFF’S CKØ MODEL}

about algebraic quantities and the way the Arabic scholars of the $9^{\text {th }}$ century did. Such a limit is perhaps a part of an explanation of the difficulties often highlighted by the community in the elaboration of a historico-mathematical activity. Pupils cannot relive the whole history of mathematics in order to learn, so some shortcuts have to be created. A way of trying to address this gap is to analyze what occurs at the last level of the $\mathrm{cK} \phi$ model. The conceptions level is the main entry point of Balacheff's model, and it is what will make our analysis centered on the students' tasks interesting. In the case of two different sets of knowledge, one contemporary and another historically situated, two sets of respective conceptions can be considered. Each conception is defined by its own quadruplet $(\mathrm{P}, \mathrm{R}, \mathrm{L}, \Sigma)$ deeply anchored in the epistemology of the mathematics at stake in a respective branch defined by $\varnothing$ (the main concept objective), a first split, $\mathrm{K}_{1}$ and $\mathrm{K}_{2}$ (the knowledge, one contemporary and the other historical), and the subsets $\mathrm{c}_{\mathrm{i}}$ and $\mathrm{c}_{\mathrm{j}}$, respectively (two sets of conceptions, each one ontologically related to its own $\mathrm{K}$ ).

Such a didactical analysis of historically based conceptions can be very helpful in the identification of the elements borrowed from history. Indeed, historians warn us of the fact that ancient mathematics has to be thought of in its own context. Even if old mathematical concepts share much with ours, the methods, the objects, and the type of argumentation are historically situated. The last three letters in cKф's definition of conceptions, R, L, and $\Sigma$, are very close to these considerations that are often regarded as the way to resituate a mathematical concept in its historical context. As said in the first part, Balacheff's works occurs within Brousseau's theory in which mathematics is defined as problem solving. When history shares this interest in the construction of concepts, the epistemological background of mathematics is often the same. Thus, for a historical conception (especially when it is at stake in a classroom activity), one should be able to identify a set of operators, $\mathrm{R}$, that are historically situated (in relationship with 


\section{HISTORY IN MATHEMATICS EDUCATION: BALACHEFF’S CKØ MODEL}

the ancient methods), an ancient system of representation, L (as a part of the ways in which ancient mathematical objects are defined/described), and the respective control structure $\Sigma$ (a witness of the argumentation system of the considered period). Different from knowledge, conceptions are easy to share, which gives a kind of justification inside the $\mathrm{cK} \varnothing$ model of what people do when they do as if.

Before going further into this theoretical analysis of the way historical elements interact with mathematics learning, let us explore a quite typical example in order to see how one can describe an activity at such a conceptions level. It will be easier next to come back to $\mathrm{P}$, the set of problems, and its potential role in activities blending history and mathematics.

\section{Application: the Indian Sulbasutras}

First, I will give some explanations on another concept I borrow from the didactics of mathematics: the task. As I said in the introduction, this paper is focused on the pupils' learning conceived as a rational construction. To identify the interactions between history and mathematics, in each exercise, one can note what has to be done. This is the pragmatic definition of task I will borrow and use in the following paragraphs. "The task-activity distinction is central to the theory of activity. The activity relates to the subject, while the task relates to the objects of the action. The definition of a task, as proposed by Leontiev and developed by Leplat is the goal to be attained under certain circumstances." (Rogalski, 2013, p.4) More precisely, in Rogalski's definition, the task takes into account the fact that the goal can express a state in the learner/knowledge relationship (Rogalski, 2003, p.349). This last aspect perfectly fits the epistemological background of the $\mathrm{cK} \phi$ model and makes an analysis at the task level potentially suitable for history in mathematics education. 


\section{HISTORY IN MATHEMATICS EDUCATION: BALACHEFF’S CKØ MODEL}

In the example that I will now detail, what is proposed by the teacher is the drawing of a square in the playground with only a rope, following a method described in an ancient Indian text that can be found in the Sulbasutras written by Baudyayana between the $5^{\text {th }}$ and $3^{\text {rd }}$ century B.C. A recent translation in French of this document is available in the last book by Delire $(2016)^{3}$. This activity has been designed by a secondary school teacher for his students (aged 1112) and has actually been implemented several times (Barrier, Mathé \& de Vittori, 2012). The teacher is not a specialist but only someone interested in the history of mathematics and its potential in mathematics teaching. His work is not inspired by the primary source translated in Delire (2016) but by a secondary paper by Keller (2000), which is also a relevant document, even if it is more oriented to the teacher's community.

What are pupils supposed to do? In the worksheet elaborated by the teacher, the first paragraph gives some information about the historical context. The Sulbasutras are treatises detailing the construction of altars, offering tables, sacred enclosures, etc., which are all necessary for the Vedic sacrifices. A small picture is also given. Then, the pupils have to follow a geometric construction directly inspired by the ancient practice.

The method used to construct a square using a rope is given below. It has been translated into actual language.

Read the text. Following this method, you will have to draw a square.

- Stretch a rope of the length corresponding to the side of the square that you want to draw.

- Mark on the ground its ends, $\mathrm{O}$ and $\mathrm{E}$, and its middle, I.

3 "Si l'on veut un carré, une méthode est de prendre une corde de longueur égale au carré donné, faire des noeuds aux deux extrémités et une marque en son milieu. On trace la ligne et on plante un piquet en son milieu. On fixe les deux noeuds au piquet et on trace un cercle avec la marque. Deux piquets sont plantés aux deux extrémités du diamètre. Un noeud étant fixé à l'est, on trace un cercle avec l'autre ; la même chose à l'ouest. Le second diamètre est obtenu des points d'intersection de ces deux ; on plante deux piquets aux deux extrémités du diamètre. Avec deux noeuds fixés à l'est, on trace un cercle avec la marque ; on fait la même chose au sud, à l'ouest et au nord. Les points d'intersection donnent le carré." (Delire, 2016, pp.75-77 and pp.217-220) 


\section{HISTORY IN MATHEMATICS EDUCATION: BALACHEFF'S CKØ MODEL}

- Draw the circle of diameter $[\mathrm{OE}]$ and the circle of radius $[\mathrm{OE}]$ (with respective centers $\mathrm{O}$ and $\mathrm{E}$ ).

- These two large circles intersect at $\mathrm{U}$ and $\mathrm{V}$.

- Stretch a rope between $\mathrm{U}$ and $\mathrm{V}$. Mark $\mathrm{N}$ and $\mathrm{S}$, its intersections with the small circle. The points $\mathrm{U}$,

$\mathrm{N}, \mathrm{I}, \mathrm{S}$ and $\mathrm{V}$ are aligned in this order.

- Trace the circles of respective centers E, O, N and S, whose radii measure half EO.

- These four circles intersect two by two at A, B, C and D.

- These four points are the vertices of the square.

By following these instructions, draw a square using the material given to you.

According to the teacher, through the historical context, the main purpose of this activity is to work in an alternative way using the definitions of some geometric objects, such as a circle, a segment, the middle, etc. In this case, the "other way" is, in fact, the historical way.

Following the $\mathrm{cK} \phi$ model, what kind of analysis can be done? The set of problems $\mathrm{P}$ of this example is related to the drawing of large-scale geometric shapes (mainly on the ground). In relation to buildings and land surveying, such mathematical problems are very common in history and currently. Nonetheless, the altars for the Vedic sacrifices are slightly special, as they are related to mysticism. In his paper, Keller (2000, p.118) explains that there are at least four important characteristics in this relationship between geometry and religion: a. the sacrificed item that is conceived has energy that is transformed by the ritual; b. the same amount of energy can take different shapes; c. in the concrete/abstract duality, mathematics is part of the ritual; and d. the priest is an identification of the demiurge, and everything should come from him (measures of the altar for instance). All these elements of historical context will be helpful in the analysis of each sub-part of the conceptions at stake.

The third item in the $\mathrm{cK} \phi$ model is the system of representation L. In this activity, one can identify two types of system of representation. The first one, $\mathrm{L}_{\mathrm{hist}}$, is the way in which the 


\section{HISTORY IN MATHEMATICS EDUCATION: BALACHEFF’S CKØ MODEL}

mathematical objects are conceived through the historical artifact that is the rope. In $\mathrm{L}_{\mathrm{hist}}$, the lines (straight) and circles represent what is possible to do with a taut rope. Similarly, the middle is what is possible to determine by folding the rope. In each of the further analyses, I will add the subscript hist to all the elements in Balacheff's characterization that are anchored in historical contents. Pupils are not ancient Indians, and in a school context, a second type of system of representation is always present, which makes this activity suitable for current mathematics teaching. All the students and the teacher as well have previously learned mathematics and the way it is contemporarily expressed. The $\mathrm{L}_{\mathrm{cont}}$ system comprises the standard way in which straight lines, circles and the middle are defined and supposed to be conceived. For instance, a circle is a set of points equidistant from a center (this definition has to be known by the pupils). As in the history related items, I will add the subscript cont (for contemporary) each time an epistemological gap between old and modern contents appears.

The set of operators $\mathrm{R}$ is the set of the geometrical constructions feasible with the chosen tools. In this specific case, for contemporary pupils, $\mathrm{R}_{\text {cont }}$ comprises everything that is possible to do with a pencil, a ruler and a compass: placing some points, drawing some circles, straight lines and intersections, and determining the middle of a segment. With a different tool, the set of operations changes, and even if the mathematical objects are the same, drawing circles or determining the middle of a segment with a rope is another type of action. All these actions, i.e., the Indians ones, are historically borrowed, that is, are included in $\mathrm{R}_{\text {hist. }}$

The last point concerns $\Sigma$, the control structure. For this activity about the Sulbasutras, the contemporarily based control $\Sigma_{\text {cont }}$ can be done in two different ways: by a visual check of the final shape (it should look like a square), and by a step by step assessment, making sure the possibility of the next phase exists in the construction program. Regarding $\Sigma_{\text {cont }}$, the 


\section{HISTORY IN MATHEMATICS EDUCATION: BALACHEFF'S CKØ MODEL}

epistemological context of the building of sacrifice altars gives clues regarding what might have been the way in which the priest checked the geometrical shape. Similar to pupils, he certainly visually checked the adequacy of the altar, but he also used his own body measures. Even if some Indians still build altars ${ }^{4}$, unfortunately, the genuine practices have certainly been lost in time, and it is almost impossible to know what the priest was really thinking. Thus, perhaps the priest thought about other mystical justifications, nobody knows. Despite this lack of precision, the historical content of the activity gives a specific $\Sigma_{\text {hist }}$ structure of control.

\begin{tabular}{|c|c|c|}
\hline & \multicolumn{2}{|c|}{ Example A: Sulbasutras, a square and a rope } \\
\hline $\mathbf{P}$ & \multicolumn{2}{|l|}{ drawing large scale geometric shapes } \\
\hline $\mathbf{R}$ & $\begin{array}{l}\mathbf{R}_{\text {cont placing some points; }} \\
\text { drawing some circles, straight } \\
\text { lines and intersections; and } \\
\text { determining the middle of a } \\
\text { segment with a ruler and a } \\
\text { compass }\end{array}$ & $\begin{array}{l}\mathbf{R}_{\text {hist placing some points with a stake; }} \\
\text { drawing some circles, straight lines and } \\
\text { intersections; and determining the } \\
\text { middle of a segment with a rope }\end{array}$ \\
\hline $\mathbf{L}$ & $\begin{array}{l}\mathbf{L}_{\text {cont the school definitions of }} \\
\text { straight lines, circles and the } \\
\text { middle }\end{array}$ & $\begin{array}{l}\mathbf{L}_{\text {hist }} \text { the lines that are possible to form } \\
\text { using a taut rope }\end{array}$ \\
\hline$\Sigma$ & $\begin{array}{l}\Sigma_{\text {cont visual check of the final }} \\
\text { shape (it should look like a } \\
\text { square) and step by step } \\
\text { assessment by making sure the } \\
\text { possibility of the next phase exists } \\
\text { in the construction program }\end{array}$ & $\begin{array}{l}\Sigma_{\text {hist }} \text { check of the final shape visually, } \\
\text { with body-based measures and perhaps } \\
\text { also mystically }\end{array}$ \\
\hline
\end{tabular}

Table 1: Application of the $\mathrm{cK} \phi$ model for an activity about Indian geometry. For the same problem P, the model reveals two different conceptions: one contemporary (subscript cont) and another historically situated (subscript hist).

4 Online, a film recorded in 1975 by Robert Gardner and J.F. Staal for The Film Study Center at Harvard University (distributed by Documentary Educational Resources) shows an Indian perpetuating the constructions of altars : http://www.der.org/films/altar-of-fire.html. 


\section{HISTORY IN MATHEMATICS EDUCATION: BALACHEFF'S CKØ MODEL}

What makes this activity unusual? At first sight, the task seems to be a simple following of the indications given in the text. However, with the help of the $\mathrm{cK} \phi$ model, one can note that two conceptions of geometrical objects are at stake in this activity. The first one $\left(\mathrm{P}, \mathrm{R}_{\text {cont }}, \mathrm{L}_{\text {cont }}\right.$, $\left.\Sigma_{\text {cont }}\right)$ comes from the school curriculum, in which a circle or a straight line is an abstract object generally driven by some definitions or properties (set of points, infinite line, ...), which represents the corresponding knowledge (the $\mathrm{K}$ in $\mathrm{cK} \phi$ ). This conception is shared by some of the pupils observed in this activity, and it is one of the aims of the teacher (school content teaching goal). However, as noted previously, a second conception appears in this work on Indian geometry. This conception $\left(\mathrm{P}, \mathrm{R}_{\text {hist }}, \mathrm{L}_{\text {hist }}, \Sigma_{\text {hist }}\right)$ is a way to identify what is brought by the historical content. In this case, a line, for instance, is what is concretely drawn when the rope is taut (here is a specific task in relationship with the $\mathrm{L}_{\text {hist }}$ system of representation). Similarly, the middle is not the point of the segment equidistant from the ends but the result of a fold. Thus, what is proposed in this activity is the creation of a bridge between a contemporary conception of the geometrical shapes and a historically situated one, and this is what makes this situation unusual. It is interesting to note that this interaction between both conceptions really appears in the implementation of this activity. During a recorded session, by themselves or with the help of the teacher, the pupils are trying to reconcile several times the conceptions at stake, which creates a really new situation for them. For instance, at the beginning of the construction, a large circle has to be drawn. A young girl simply takes the chalk and traces freehand a closed curve. Discussing with the teacher, she explains that she considered a usual round shape ${ }^{5}$, which is justified by the unusual situation created by the use of a new tool (the rope). The teacher reminds

5 "un rond normal" she says in French. 


\section{HISTORY IN MATHEMATICS EDUCATION: BALACHEFF’S CKØ MODEL}

her of some knowledge regarding the circle (center, equidistance) corresponding to its contemporary conception. This enables a final step in which she thinks about the usefulness of the taut rope, thus connecting both conceptions and taking this epistemological bridge to improve her school knowledge regarding the circle. Some similar moments regarding the middle of the segment are also notable. In the second step of the geometrical construction, students have to find the middle of the segment $[\mathrm{OE}]$. One of the groups of pupils has placed the point I at an equal distance from $\mathrm{O}$ and $\mathrm{E}$ but not aligned with these two points. In this case, the students try to apply an element of the contemporary conception of the middle (the middle is equidistant to both ends), but they omit the alignment. With the teacher's help, they are invited to remember the role of the tautness of the rope and its mathematical meaning. Therefore, the pupils go back and forth from one conception to another, which creates once again a specific situation conducive for school-provided learning.

In this example, the use of history in mathematics teaching produces new specific tasks in which students connect two conceptions, one coming from their own school experience and another borrowed from the given historical context. I will now come back to the discussion about the way conceptions (contemporary and historical ones) interact in the classroom and how the c, $\mathrm{K}, \varnothing$ typology can be useful in general to make the way of interaction explicit.

\section{Student conceptions and Balacheff's problem-conception duality}

In the beginning of this paper, I noted the importance of the epistemological anchoring of the $\mathrm{cK} \phi$ model. This model proposes an analysis based on three different levels, ranging from the most individualized one (pupils' conceptions) to the most abstract one (the mathematical concepts). In this organization, knowledge is situated somewhere halfway in this range and is 


\section{HISTORY IN MATHEMATICS EDUCATION: BALACHEFF'S CKØ MODEL}

representative of any teaching situation in which school contents must be stabilized in the end. By nature, the contemporary knowledge $\mathrm{K}_{\text {cont }}$ is incommensurable with the historical one $\mathrm{K}_{\text {hist }}$, but we have seen in the previous parts that a good level for the study consists of conceptions analysis. In any contemporary classroom, on any mathematical topic, many conceptions $\left(\mathrm{c}_{\mathrm{stu}}\right.$, $\mathrm{c}_{\text {stu2, }}$ etc.) are at stake in students' works. The main unique quality of the use of history is the addition of a new conception characterized by its own quadruplet $\left(\mathrm{P}, \mathrm{R}_{\text {hist }}, \mathrm{L}_{\text {hist }}, \Sigma_{\text {hist }}\right)$, which appears at a more or less extensive distance from the students' contemporary conceptions. What about P? In the $\mathrm{cK} \phi$ model, problems and conceptions are deeply connected. The relationships between problems and conceptions are multiple.



Figure 1: Relationships between problems (P) and conceptions (C) in Balacheff's cK $\varnothing$ model

In Balacheff's paper (2013, p.12), a small diagram summarizes this idea (Figure 1, where P stands for problems and $\mathrm{C}$ for conceptions), and in complete agreement with the TDS in the background, the author explains that "learning is a process whose outcome is an evolution of conceptions being reinforced, questioned or transformed. The motor of this process is problems, which are (in our terms) destabilizations of the learner/milieu system." A problem can activate, 


\section{HISTORY IN MATHEMATICS EDUCATION: BALACHEFF'S CKØ MODEL}

reinforce, destabilize or simply relate to one or more conceptions. These possibilities are often used in sessions blending mathematics and history, and with this model, such relationships in students' conceptions can be anticipated and analyzed. In the use of history in mathematics education, through a new problem $\mathrm{P}_{+}$comprising specific tasks, pupils can be put in touch with conceptions borrowed from the past. Due to the gap between $K_{\text {cont }}$ and $K_{\text {hist }}$, in order to be meaningful for the students, the conceptions related to $\mathrm{P}_{+}$have to be compatible with $\mathrm{K}_{\text {cont }}$, which is the only one available to pupils. When $\mathrm{P}_{+}$is part of both conceptions, i.e., part of both $\left(\mathrm{P}_{+}, \mathrm{R}_{\text {hist }}, \mathrm{L}_{\text {hist }}, \Sigma_{\text {hist }}\right)$, its historical anchorage, and $\left(\mathrm{P}_{+}, \mathrm{R}_{\text {cont }}, \mathrm{L}_{\text {cont }}, \Sigma_{\text {cont }}\right)$, its contemporary meaning in students' mind, it creates a bridge between the students' contemporary conceptions and their historically situated ones (Figure 2 ). In this way, a new conception ( $\mathrm{c}_{\text {hist }}$ in Figure 2 , for instance, the Indian conception in the activity analyzed in part 3) enters the set of conceptions usable by the student and thus enables an enrichment of the related knowledge $\left(\mathrm{K}_{\text {contemporary }}\right.$ in Figure 2, for instance, the $6^{\text {th }}$ grade class knowledge learned in the activity analyzed in part 3).



Figure 2: On a specific mathematical topic $\phi$, the contemporary knowledge at stake in a class or in a group of students is not the ancient one. A new problem $\mathrm{P}_{+}$creates a bridge that enables contact between students' 


\section{HISTORY IN MATHEMATICS EDUCATION: BALACHEFF'S CKØ MODEL}

conceptions and a historically situated one.

Generally, the role of $\mathrm{P}_{+}$can vary. Depending on the pedagogical choices of the teacher, $\mathrm{P}_{+}$can be a way to activate a new conception, to reinforce one, to destabilize a previous set of conceptions, etc. (Figure 1). Only case studies on precise empirical data would enable further conclusions on this point.

\section{Conclusion: the what and where in empirical studies}

In this paper, I have tried to show how a model borrowed from the pure didactics of mathematics can be useful for empirical studies on the use of history in mathematics education. The cK $\varnothing$ model, whose application does not seem to be specific to my example as soon as teaching goals and epistemological backgrounds are close enough, appears to be helpful in the

analysis of the interaction between historically situated elements (conceptions borrowed from the past) and the usual mathematics learning (at the students' conceptions level). At a more conceptual level, such type of import raises fundamental questions about the theoretical background underlying any model in education. In his deep analysis of the possible connections between theories in education, Radford (2008) underlines the role of principles that lead them and the fact that methods and questions are not necessarily logical consequences of those principles (Radford, 2008, p.324). Balacheff's ck $\varnothing$, as explained at the beginning of this text, is anchored in Brousseau's theory which is very different from Jahnke's perspective. However, both can share the same questioning about the interactions between ancient and contemporary mathematics in a teaching context.

The recent quantitative increase of empirical studies on the use of history in mathematics education is leading to the emergence of new questions which, more or less explicitly, relate to a 


\section{HISTORY IN MATHEMATICS EDUCATION: BALACHEFF’S CKØ MODEL}

quest for evidence of the efficiency this pedagogical approach. Indeed, even the best theoretical framework cannot ensure teachers, educators and parents that pupils will learn, especially in an unusual situation. Empirical studies, which deal with real classrooms and precise teaching goals, give an outlook on pupils' learning. Thus, in an activity blending mathematics and history, one can ask where each field appears and what knowledge is really involved. "Where" is here as much a spatiotemporal question (Where does history appear in the activity? At the beginning? At the end? In between?) as a conceptual one (During the learning process, where is history at stake?). Such a questioning can be considered as the micro version of Jankvist's (2009) categorization of the hows and whys of the use of history. "What" is, may be, the most important question as it is focused on knowledge which is the aim of any education. Whether the teacher chooses to use history as a tool or as a goal what is learned by students is always his main interest. Empirical studies create a kind of zoom on some specific aspects a suitable model should be able to deal with. It is interesting to notice that, however history is implemented, the educators always express their attachment to a kind of specificity hardly definable. Such a grey zone is exactly where research needs to focus. 


\section{HISTORY IN MATHEMATICS EDUCATION: BALACHEFF’S CKØ MODEL}

\section{References}

Artigue, M. (1991). Épistémologie et didactique [Epistemology and didactics]. Recherches en didactique des mathématiques. Grenoble: Éditions La Pensée Sauvage, 10(2/3): 241-285.

Balacheff N., \& Margolinas C. (2005). cKф Modèle des connaissances pour le calcul de situation didactiques [cK $\not$ Knowledge model for the calculating of didactical situations]. In Mercier A. \& Margolinas C. (eds.) Balises pour la didactique des mathématiques. Grenoble: Éditions La Pensée Sauvage, 1-32.

Balacheff, N. (2013). cK $\varnothing$, a model to reason on learners' conceptions. In Martinez, M. \& Castro Superfine, A (Eds.). Proceedings of the 35th annual meeting of the North American Chapter of the International Group for the Psychology of Mathematics Education. Chicago, IL: University of Illinois at Chicago, 2-15.

Barbin, É., Guichard, J.-P., Moyon, M., Guyot, P., Morice-Singh, C., Métin, F., Bühler, M., Tournès, D., Chorlay, R., \& Hamon, G. (2018). Let History into the Mathematics Classroom. Springer international publishing.

Barrier, T., Mathé, A.-C., \& de Vittori, T. (2012). Des séances ordinaires comportant une dimension historique: quels enseignements? [Regular sessions with a historical dimension: what lessons?]. Petit x, Grenoble: IREM de Grenoble, 90: 5-34.

Bråting, K. \& Pejlare, J. (2015). On the relations between historical epistemology and students' conceptual developments in mathematics. Educational Studies in Mathematics, 89(2): 251-265.

Brousseau, G. (1997). Theory of didactical situations in mathematics. Dordrecht: Kluwer.

Clark, K., Kjeldsen, T.H., Schorcht, S., Tzanakis, C., \& Wang, X. (2016). History of mathematics in mathematics education - Recent developments. In Radford, L., et al. Proceedings of 


\section{HISTORY IN MATHEMATICS EDUCATION: BALACHEFF'S CKØ MODEL}

the 2016 ICME Satellite Meeting of the International Study Group on the Relations Between the History and Pedagogy of Mathematics. Montpellier, France: IREM de Montpellier, 135-179.

Delire, J.-M. (2016). Les mathématiques de l'autel védique. Le Baudhāyana Śulbasūtra et son commentaire Ślbadīikikā. Édition critique, traduction et commentaire [The mathematics of the Vedic altar. The Baudhāyana Śulbasūtra and his comment Śulbadīpikā. Critical edition, translation and commentary]. Genève : Librairie Droz.

de Vittori, T. (2016). Analysis of pupils tasks in the use of history in mathematics teaching. In Radford, L., et al. Proceedings of the 2016 ICME Satellite Meeting of the International Study Group on the Relations Between the History and Pedagogy of Mathematics. Montpellier, France: IREM de Montpellier, 675-684.

Fried, M. N. (2008). History of mathematics in mathematics education: A saussurean perspective. The Montana Mathematics Enthusiast, 5(2): 185-198.

Fried, M. N. (2014a). History of Mathematics and Mathematics Education. In Michael R. Matthews (Ed.), History, philosophy and science teaching handbook, volume I. New York: Springer, 669-705.

Fried, M. N. (2014b). Our relationship to the mathematical past. Lecture for the MAA-AMS Joint Conference - Short Course on Historiography. Baltimore, Maryland, USA.

Fried, M., Guillemette, D., Jahnke, H.N. (2016). Theoretical and/or conceptual frameworks for integrating history in mathematics education. In Radford, L., et al. Proceedings of the 2016 ICME Satellite Meeting of the International Study Group on the Relations Between the History and Pedagogy of Mathematics. Montpellier, France: IREM de Montpellier, 211-230. 


\section{HISTORY IN MATHEMATICS EDUCATION: BALACHEFF'S CKØ MODEL}

Grugnetti, L., Rogers, L., Carvalho e Silva, J., Daniel, C., Coray, D., de Guzmán, M., Gispert, H., Ismael, A., Jones, L., Menghini, M., Philippou, G., Radford, L., Rottoli, E., Taimina, D., Troy, W., \& Vasco, C. (2002). Philosophical, multicultural and interdisciplinary issues, History in Mathematics Education - New ICMI Study Series, Fauvel, J. \& Van Maanen, J. (Eds), vol.6: 39-62.

Guillemette, D. (2015). L'histoire des mathématiques et la formation des enseignants du secondaire : Sur l'expérience du dépaysement épistémologique des étudiants. Doctoral thesis, Université du Québec à Montréal, Montréal, Canada. Retrieved from http://www.archipel.uqam.ca/7164/1/D-2838.pdf.

Jahnke, H. N. (2014). History in mathematics education. A Hermeneutic Approach. In M. Fried, \& T. Dreyfus (Eds.), Mathematics \& mathematics education: Searching for common ground, Dordrecht: Springer, 75-88.

Jankvist, U. T. (2009). A categorization of the "whys" and "hows" of using history in mathematics education. Educational Studies in Mathematics, 71(3): 235-261.

Katz, V. J., Jankvist, U. T., Fried, M.N. et al. (2014). Special Issue on History and Philosophy of Mathematics in Mathematics Education. Science \& Education, 23: 1.

Keller, O. (2000). La géométrie des Sulbasutras. Exemple de géométrie rituelle de l'Inde védique : l'agrandissement de l'autel en forme de faucon [The geometry of Sulbasutras. Example of ritual geometry of Vedic India: the extension of the falcon-shaped altar]. France: Repères-IREM, 40: 115-124.

Kidron, I. (2016). Epistemology and networking theories. Educational Studies in Mathematics, 91(2): 149-163.

Lim, S. \& Chapman, E. (2015). Effects of using history as a tool to teach mathematics on 


\section{HISTORY IN MATHEMATICS EDUCATION: BALACHEFF'S CKØ MODEL}

students' attitudes, anxiety, motivation and achievement in grade 11 classrooms. Educational Studies in Mathematics, 90: 189.

Morange, M. (2008). À quoi sert l'histoire des sciences ?[What is the history of science for?], Versailles: Quae.

Radford, L. (2008a). Connecting theories in mathematics education: challenges and possibilities. ZDM - The International Journal on Mathematics Education, 40, 317-327.

Radford, L., Furinghetti, F., \& Hausberger, T. (Eds.) (2016). Proceedings of the 2016 ICME Satellite Meeting of the International Study Group on the Relations Between the History and Pedagogy of Mathematics. Montpellier, France: IREM de Montpellier.

Rogalski, J. (2003). Y-a-t'il un pilote dans la classe ? Une analyse de l'activité de l'enseignant comme gestion d'un environnement dynamique ouvert. [Is there a driver in the class? An analysis of the teacher's activity as management of an open dynamic environment], Recherches en Didactique des Mathématiques, 23 (3): 343-38.

Rogalski, J. (2013). Theory of activity and developmental frameworks for an analysis of teachers' practices and students' learning. In Mathematics classrooms: students' activities and teachers' practices, Vandebrouck, F. (Ed.), Sense Publishers.

Wang, K., Wang, X., Li, Y., \& Rugh, S. (2018). A framework for integrating the history of mathematics into teaching in Shanghai, Educational Studies in Mathematics, 98:135-155. 